\title{
Motif dan Proses Psikologis Korupsi
}

\author{
Nadiatus Salama ${ }^{1}$ \\ Fakultas Dakwah dan Komunikasi, IAIN Walisongo Semarang
}

\begin{abstract}
A qualitative phenomenological study was conducted to identify and describe the phenomenon of corruption psychology. Two corruptors were interviewed to explore their perceptions on corrupt practices in Central Java. The interview conducted to explore informant perceptions on a real process. Interview data collected resulted in five themes: (1) Corruption is an act of abuse the authority, identical with theft, something that not run correctly, and using public money for personal and group interest intentionally; (2) The motives of the informants in doing corruption are solidarity with the friends' doer, system that enables to corrupt, to earn much more money, and make friends; (3) Process of corruption; budget-making has been done by legislative and executive institution; marking-up the budget, facilities and allowances; reporting the administrative data manipulatively; interrelating chain in corruption process; and distributing the aspiration fund without a proof of receipts; (4) The impact of corruption is making someone's wiser in life, putting the corruptors in to the jail, humiliating their big family, and also, having a more debt, and (5) The settlement of problems that they employ is by using emotion-focused coping.
\end{abstract}

Keywords: corruption, phenomenology, motive, impact, coping

Abstrak. Penelitian kualitatif fenomenologi ini dilakukan untuk mengidentifikasi dan menggambarkan fenomena psikologi korupsi. Dua pelaku korupsi diwawancarai untuk menggali persepsi makna pengalamannya dalam melakukan proses korupsi yang terjadi di Jawa Tengah. Data penelitian menghasilkan lima tema, yaitu: (1) Definisi korupsi, yaitu penyalahgunaan jabatan, identik dengan pencurian, tidak berjalan sesuai dengan aturan yang sesungguhnya, dan penggunakan uang negara secara sengaja untuk kepentingan pribadi maupun kelompok; (2) Motif melakukan korupsi, yaitu karena faktor solidaritas dengan teman-temannya, adanya sistem yang memungkinkan terjadinya korupsi, untuk mendapatkan uang dan pekerjaan; (3) Proses terjadinya korupsi, yaitu pembuatan anggaran yang dilakukan oleh lembaga legislatif bersama dengan lembaga eksekutif, memperbesar anggaran, fasilitas maupun tunjangan untuk kepentingan mereka, laporan administratif dimanipulasi, mata rantai korupsi yang saling berkaitan, dan penyaluran dana aspirasi tanpa memakai bukti kuitansi; (4) Dampak terhadap pelaku korupsi, yaitu mendapatkan hikmah hidup yang berharga; masuk penjara; berdampak pada keluarga dan memiliki hutang baru yang lebih besar; serta (5) Cara mengatasi masalah (coping) akibat korupsi, yaitu menggunakan emotion focused coping.

Kata kunci: korupsi, fenomenologi, motif, dampak, koping

Korupsi merupakan fenomena yang selalu menarik perhatian dan mengundang opini publik. Korupsi menjadi tema yang penting untuk dijadikan bahan

\footnotetext{
${ }^{1}$ Korespondensi mengenai isi artikel ini dapat dilakukan melalui: salama_nadia@yahoo.com
}

kajian karena terkait dengan banyaknya penelitian yang menunjukkan adanya dampak negatif dari korupsi. Menurut estimasi lembaga Bank Dunia, jumlah uang yang nilainya lebih dari US\$ 1 triliun telah dipergunakan untuk menyuap setiap tahunnya. Sementara itu, jumlah kerugian 
akibat korupsi yang terjadi di negara berkembang telah mencapai hampir US\$ 80 miliar pertahunnya.

Praktik korupsi tidak lagi hanya sebatas kejahatan struktural dan pelanggaran moral, tapi lebih dari itu, korupsi telah menciptakan banalitas korupsi. Banal, sama artinya menjadikan korupsi sebagai sesuatu yang lumrah, biasa, wajar, bahkan menjadi prinsip penggerak kehidupan seharihari (Purwantari, 2010). Korupsi telah mengakar dan cenderung diterima oleh masyarakat banyak. Saat ini telah muncul situasi tidak adanya lagi budaya malu untuk melakukan korupsi, serta salah persepsi dan salah pengertian akan dampak negatif korupsi terhadap perkembangan politik, ekonomi dan sosial.

Kesejahteraan masyarakat tidak akan tercapai manakala praktik korupsi masih tetap berjalan aman dan terpelihara. Negara yang korup akan memiliki tingkat pencurian dan penggelapan pajak yang tinggi. Korupsi juga sering membuat aturan bisnis yang dipermudah; atau aturan yang bisa menghambat pasar dan memaksa para investor untuk membayar lebih mahal. Korupsi bisa menurunkan jumlah anggaran yang disediakan untuk berbagai program pemerintah, termasuk Gross Domestic Product (GDP = Produk Domestik Kasar) dan pembiayaan untuk sektor publik, seperti pendidikan serta program pemerataan ekonomi. Negara yang korup juga cenderung kurang efisien dan kurang stabil dalam menjalankan pemerintahannya serta kurang responsif terhadap keinginan masyarakat (Graeff, dalam Lambsdorff \& Schramm-ed., 2005).

Membasmi korupsi merupakan sarana korupsi untuk memperbaiki ekonomi di negara-negara berkembang, khususnya di Indonesia. Salah seorang pendiri lembaga Transparansi Internasional, Jeremy Pope, menyatakan bahwa tujuan dari kebijakan anti-korupsi adalah:

"Membasmi korupsi tidak bertujuan untuk mengakhiri korupsi semata, tapi lebih pada suatu cara untuk membuat pemerintah menjadi lebih efektif, efisien, dan adil (Pope, 1999)."

Meski korupsi merupakan suatu tindakan yang ilegal, namun tidak berarti korupsi akan dianggap sebagai tindakan yang melawan hukum, bahkan oleh mereka yang berwenang dalam mengambil keputusan dibidang hukum sekalipun. Korupsi, terkadang, bisa ditoleransi meski kenyataannya semua orang tahu bahwa tindakan tersebut ilegal dan melanggar norma masyarakat/publik. Di beberapa negara, perilaku yang melawan hukum ini bisa diterima, meski di negara lain yang telah memiliki aturan yang tegas, hal ini bisa mengundang reaksi keras (Schweitzer, 2005).

Meningkatnya perhatian dunia terhadap isu korupsi telah membuka jalan diadakannya banyak penyelidikan tentang hal ini. Namun, korupsi seringkali dilihat sebagai sesuatu yang terkait dengan faktor ekonomi, hukum, politik, dan kekuasaan, dan sangat jarang dikaitkan segi yang lain, yaitu suatu dimensi yang melekat pada manusia, khususnya dimensi perilaku (behavior).

Huntington (1968) mendefinisikan korupsi sebagai "behavior of public officials which deviates from accepted norms in order to serve private ends". Korupsi merupakan perilaku yang menyimpang dari normanorma yang diterima dan dianut masyarakat dengan tujuan untuk mendapatkan keuntungan pribadi yang dilakukan oleh para pegawai publik. Korupsi ibarat bayangan yang akan selalu mengikuti kemanapun subjek kekuasaan berada, dimana ada wewenang dan kekuasaan, 
maka korupsi akan berada tidak jauh dari situ.

Secara umum, pengertian korupsi harus melekat dengan ranah publik (Muluk, 2008). Korupsi berasal dari bahasa Latin 'corruptus' (merusak habis-habisan). Sehingga, bisa diartikan bahwa korupsi merupakan tindakan yang merusak secara keseluruhan kepercayaan masyarakat kepada pelaku korupsi, yang bahkan juga bisa menghancurkan seluruh sendi kehidupan bermasyarakat dan bernegara (Wignjosubroto, 2004). Sementara itu, di sisi lain, korupsi (corrupt, corruptie, corruptio) juga bisa bermakna kebusukan, keburukan, dan kebejatan. Definisi ini juga didukung oleh Acham yang mengartikan korupsi sebagai suatu tindakan yang menyimpang dari norma masyarakat dengan cara memperoleh keuntungan untuk diri sendiri serta merugikan kepentingan umum (Acham, dalam Brünner (ed.), 1981). Intinya, korupsi adalah menyalahgunakan kepercayaan yang diberikan publik atau pemilik untuk kepentingan pribadi (Alatas, 1987). Sehingga korupsi menunjukkan fungsi ganda yang kontradiktif, yaitu memiliki kewenangan yang diberikan publik yang seharusnya untuk kesejahteraan publik, namun digunakan untuk keuntungan diri sendiri (Darsono, 2001).

Korupsi merupakan kejahatan yang dilakukan dengan penuh perhitungan oleh mereka yang justru merasa sebagai kaum terdidik dan terpelajar (Masduki, 2010). Korupsi juga bisa dimungkinkan terjadi pada situasi dimana seseorang memegang suatu jabatan yang melibatkan pembagian sumber-sumber dana dan memiliki kesempatan untuk menyalahgunakannya guna kepentingan pribadi. Nye (1967) mendefinisikan korupsi sebagai perilaku yang menyimpang dari tugas formal sebagai pegawai publik untuk mendapatkan keuntungan finansial atau meningkatkan status. Selain itu, juga bisa diperoleh keuntungan secara material, emosional, ataupun simbol.

Berkaitan dengan definisi di atas, korupsi tidak hanya menyangkut aspek hukum, ekonomi dan politik saja tetapi juga menyangkut aspek perilaku manusia yang menjadi bahasan utama dari ilmu psikologi. Korupsi juga perlu diteliti dengan pendekatan psikologi karena problem korupsi di Indonesia merupakan persoalan besar yang berbeda dengan tindak kriminal biasa, bahkan sering pula disebut sebagai extraordinary crime (kejahatan luar biasa) dan crimes against humanity (kejahatan terhadap kemanusiaan). Banyak rakyat yang terbelit kemiskinan karena uang yang seharusnya mengalir kepada mereka telah habis dikorupsi oleh para koruptor.

Jajak pendapat yang dilakukan oleh Litbang Harian Kompas menunjukkan bahwa penyebab perilaku korupsi, yaitu: (1) Didorong oleh motif-motif ekonomi, yakni ingin memiliki banyak uang secara cepat meski memiliki etos kerja yang rendah, (2) Rendahnya moral, dan (3) Penegakan hukum yang lemah (Purwantari, 2010). Sementara itu, menurut Rudel dan Xin (2004), korupsi terjadi karena adanya monopoli kekuasaan, lemahnya akuntabilitas suatu institusi, serta besarnya wewenang yang diberikan pada seseorang. Adanya ketidakadilan dan perlakuan yang tidak sama juga turut memunculkan terjadinya korupsi (Alesina \& Angeletos, 2005).

Korupsi seringkali terjadi dengan mengalahkan suatu hubungan persahabatan yang sebelumnya terjalin baik dan tulus. Proses korupsi bisa terjadi secara samar, licin, dan sangat licik. Motif seseorang dalam melakukan korupsi tidak hanya untuk memperoleh keuntungan 
secara materi, tapi juga agar bisa meningkatkan hubungan pertemanan, percintaan, status, dan pencitraan, serta membuat orang lain jadi terkesan, terpesona, dan mudah terpengaruh (Graaf \& Huberts, 2008).

Modus operandi korupsi, menurut Regar (1998), bisa dengan cara: (1) menaikkan harga pembelian/pengeluaran; (2) menurunkan harga penjualan/penerimaan; (3) memanipulasi catatan; (4) memalsukan dokumen; (5) menghilangkan dokumen; (6) mencuri; (7) memalsukan kualitas barang; serta (8) membuat peraturan yang hanya membela atau menguntungkan pihak tertentu saja.

Korupsi bisa terjadi melalui berbagai jenis dan metode. Berikut ini empat klasifikasi korupsi menurut Morgan (1998), yaitu: (1) suap, (2) nepotisme dan klientelisme, (3) penggelapan dan penipuan, dan (4) penyalahgunaan kekuasaan.

Jenis-jenis korupsi, menurut Schacter dan Shah (2000), meliputi hal-hal berikut: (1) Korupsi birokrasi atau pejabat yang melibatkan sejumlah besar pejabat pemerintah (birokrat dan politisi), termasuk suap skala kecil dan pemberian bantuan. (2) Korupsi besar-besaran yang merupakan pencurian atau penyelewengan sejumlah besar dana masyarakat tapi dilakukan oleh beberapa pejabat yang jumlahnya relatif kecil, dan (3) Penyalahgunaan kekuasaan yang diberikan negara atau penyimpangan peraturan yang melibatkan kolusi antara perusahaan swasta dengan instansi-instansi pemerintah untuk kepentingan pribadi.

Alatas (1975) menyebutkan ciri-ciri korupsi, antara lain: (1) Biasanya melibatkan lebih dari satu orang, (2) Terkait dengan sesuatu yang serba rahasia kecuali yang telah berakar, (3) Melibatkan elemen kewajiban dan keuntungan timbal balik (tidak selalu materi/uang), (4) Pelaku biasanya berlindung dibalik pembenaran hukum, (5) Pelaku adalah orang yang berpengaruh dalam mengambil keputusan, (6) Mengandung penipuan kepada badan publik atau masyarakat umum, (7) Pengkhianatan kepercayaan, (8) Melibatkan fungsi ganda yang kontradiktif, (9) Melanggar norma-norma tugas dan pertanggungjawaban, (10) Kepentingan umum dibawah kepentingan pribadi/ golongan.

Dampak korupsi yang lain bisa berupa: (1) Runtuhnya akhlak, moral, integritas, dan religiusitas bangsa, (2) Adanya efek buruk bagi perekonomian negara, (3) Korupsi memberikan kontribusi bagi matinya etos kerja masyarakat, (4) Terjadinya eksploitasi sumber daya alam oleh sekelompok orang, serta (5) Memiliki dampak sosial dengan merosotnya human capital (Na'im dkk., 2006). Di samping itu, menurut Fleming (2004), korupsi dalam berbagai organisasi telah menyebabkan kerusakan ekonomi yang sangat besar dan hilangnya kepercayaan para stakeholders (pemangku kepentingan).

Upaya pemberantasan korupsi tidak hanya dilakukan oleh pemerintah dengan membuat Undang-Undang (UU) Nomor 3 Tahun 1971 yang diperbarui dengan UU Nomor 31 Tahun 1999 tentang Pemberantasan Tindak Pidana Korupsi, UU Nomor 28 Tahun 1999 tentang Penyelenggaraan Negara yang Bersih dan Bebas dari Korupsi, Kolusi dan Nepotisme, dan yang terbaru UU Nomor 20 Tahun 2001 tentang Perubahan atas UU Nomor 31 Tahun 1999 tentang Pemberantasan Tindak Korupsi, dan juga dengan membentuk lembaga khusus seperti Komisi Pemberantasan Korupsi (KPK). Di samping itu, pemerintah melalui Peraturan Presiden RI Nomor 55 Tahun 2012 telah mengeluarkan Strategi Nasional Pencegahan dan Pemberantasan Korupsi (Stranas PPK) jangka 
menengah tahun 2012-2014 dan jangka panjang tahun 2012-2025.

Semakin tinggi tingkat korupsi sebuah negara maka dibutuhkan sebuah upaya yang keras untuk membangun sistem pengawasan dan penegakan hukum. Korupsi yang berakar kuat memerlukan pengawasan dari pihak legislatif, serta memiliki peradilan yang baik, mandiri dan sumber daya manusia yang kompeten pula untuk mengaudit kinerja pemerintah. Di samping itu, diperlukan juga ruang bagi media independen dan masyarakat sipil untuk mengawasi pemerintah agar lebih transparan dalam mengalirkan dana kepada publik.

Jadi, korupsi bukan saja persoalan individual, tetapi merupakan persoalan sistemik karena hal ini bisa terjadi pada berbagai lini kehidupan yang menjangkiti siapa saja yang berada di dekatnya tanpa pandang bulu. Korupsi, sebagai sebuah perilaku, dipengaruhi oleh berbagai faktor, baik faktor sosial maupun faktor individual. Namun demikian, pendekatan individual terhadap perilaku korupsi kurang mendapat perhatian. Oleh karenanya, penelitian ini mencoba untuk menggali dan menganalisis dari sisi psikologis pelaku korupsi.

Kajian tentang korupsi ini bertujuan untuk memberikan gambaran tentang perilaku korupsi yang nantinya diharapkan bisa menjadi data bagi pemerintah, akademisi, LSM aktivis antikorupsi serta institusi terkait untuk menyusun perencanaan kebijakan dalam meningkatkan upaya pendidikan dan budaya anti korupsi.

Sejak awal tahun 1900-an, psikologi telah dijajagi untuk masuk ke wilayah hukum guna membantu terwujudnya keadilan. Psikologi yang terkait dengan wilayah hukum bernaung dalam suatu studi yang disebut dengan "psikologi dan hukum". Secara garis besar, ada sejumlah studi yang fokus pada masalah ini, yaitu: (1) Psikologi penegakan hukum, Psikologi untuk menangani narapidana baru, (3) Psikologi forensik, dan (4) Psikologi hukum (Lianawati, 2009).

Selama ini, hasil penelitian dari psikologi hukum lebih banyak yang didasarkan pada penelitian eksperimental, bukan penelitian lapangan (Lianawati, 2009). Bidang yang akan dikaji ini adalah penelitian lapangan yang berpijak pada proses hukum yang secara nyata dialami oleh informan. Beranjak dari fenomena korupsi di atas, maka peneliti mengajukan rumusan masalah: Bagaimana makna pengalaman melakukan korupsi?

\section{Metode}

Terbatasnya kajian penelitian yang bertemakan tentang makna pengalaman hidup pelaku korupsi mendorong peneliti untuk menyajikan suatu studi kualitatiffenomenologi guna lebih memahami fenomena yang terjadi dalam korupsi ini. Peneliti memilih pendekatan fenomenologi dalam memaparkan makna pengalaman hidup individu saat melakukan korupsi karena penelitian ini; (1) menjelaskan pengalaman hidup informan yang dimaknai secara subjektif oleh mereka sendiri (Taylor, 1993), serta (2) mencari inti dari makna pengalaman yang dialami oleh individu (Drew, 1989).

Informan dipilih dengan menggunakan prosedur pengambilan sampel teoretis (theoretical sampling), dalam hal ini informan yang dipilih adalah mereka yang mampu memberikan informasi sesuai dengan fokus dan tujuan dari penelitian ini (Creswell, 1998). Penelitian ini dilakukan untuk mengungkap kasus-kasus dugaan korupsi, yang terjadi di tingkat lokal. Lokasi penelitian yang terpilih adalah di Surakarta, Jawa Tengah. Data 
dalam penelitian ini diperoleh dari: (1) Sumber data primer, yaitu mereka yang menjadi pelaku korupsi, yang telah selesai menjalani hukuman pidana di Lembaga Pemasyarakatan Surakarta (X, mantan anggota DPRD Surakarta, ditahan karena adanya tuduhan korupsi dengan melakukan mark up anggaran dana APBD Surakarta tahun 2003) dan yang sedang menjalani hukuman pidana di Lembaga Pemasyarakatan Surakarta (Y ditahan karena dituduh melakukan korupsi dana aspirasi senilai Rp 250 juta), serta melalui penggalian dokumen yang terkait, seperti media massa dan hasil penelitian; dan (2) Sumber data sekunder diperoleh dari LSM Masyarakat Anti Korupsi Indonesia (MAKI), serta berbagai literatur yang mendukung penelitian ini.

Wawancara dilakukan selama kurang lebih 45 menit dengan melibatkan dua orang (Polkinghorne; dalam Creswell, 1998). Jumlah informan yang berkisar antara 2 sampai 10 ini dirasa sudah cukup karena telah memenuhi persyaratan metodologi untuk sebuah penelitian fenomenologi (Dukes; dalam Creswell, 1998).

Penelitian dilakukan dengan wawancara secara intensif dan mendalam (indepth-interview) yang memfokuskan pada bagaimana pikiran, perasaan, dan tindakan informan saat melakukan korupsi, dampak yang terjadi, serta strategi copingnya (Moustakas, 1994). Pertanyaan terbuka (open-ended questions) yang diajukan bertujuan untuk memberikan kebebasan kepada informan dalam menjawab secara terbuka dan terinci tentang apa yang mereka ingin sampaikan tanpa diatur ketat oleh peneliti. Analisis dalam penelitian ini bersifat induktif dan berkelanjutan yang tujuan akhirnya adalah menghasilkan gambaran tentang makna pengalaman hidup pelaku berkenaan dengan fenomena korupsi.

\section{H a s i 1}

Proses penelitian untuk mengungkap kasus ini banyak menemui hambatan dalam perjalanannya. Tema mengenai psikologi korupsi merupakan hal yang personal, sensitif, dan cenderung ditutupi oleh mereka yang melakukannya. Hal mendasar yang menghambat penyusunan penelitian ini terletak pada sulitnya untuk menemui mereka agar mau 'bicara', dan ini bukanlah perkara yang mudah.

Penelitian ini memfokuskan pada penggalian makna pengalaman melakukan korupsi. Guna menggali makna pengalaman dari informan seputar korupsi maka peneliti merasa perlu mengetahui terlebih dulu alasan, dinamika pengalaman, serta dampak melakukan korupsi terhadap informan ini. Berdasarkan hasil wawancara, tampak bahwa pengalaman melakukan korupsi ini bersifat sangat personal dan berbeda-beda antara informan satu dengan yang lain.

Ada dua bentuk/tipe korupsi yang bisa dilihat dari hasil penelitian ini, yaitu korupsi dengan tipe sistemik dan sistematik (Tempo, 19/2/2001). Korupsi sistemik merupakan kombinasi antara politik dan korupsi yang dilaksanakan secara teratur, tersistem dan terstruktur. Sementara, pada korupsi sistematik yang terjadi dalam penelitian ini adalah para pelaku korupsi membeli loyalitas dengan cara membagikan sejumlah uang kepada para pemilihnya (konstituen). Para konstituen harus disuap terus-menerus karena jika jumlah suapan yang diberikan pihak kompetitor lebih besar, maka konstituen kemungkinan akan menyeberang dan berpindah untuk memilih pihak lawan pada pemilu periode yang akan datang.

Mengingat penelitian ini menggunakan pendekatan kualitatif serta terbatasnya jumlah informan dan jumlah kasus 
korupsi yang dijadikan sebagai sumber data dalam penelitian ini maka hasil penelitian ini tentu saja tidak bisa digeneralisir atau dijadikan acuan untuk menjelaskan banyaknya kasus yang sama yang juga terjadi di wilayah lain di Indonesia. Sebagai gambaran singkat tentang kasus korupsi yang diangkat, peneliti memaparkan sekilas tentang kasus korupsi yang terjadi.

\section{Kasus Korupsi Sistemik oleh $\boldsymbol{X}$}

$\mathbf{X}$ berusia 37 tahun, pendidikan sarjana, mantan anggota DPRD Surakarta, anggota panitia anggaran rumah tangga, dihukum tiga tahun penjara karena melakukan korupsi APBD DPRD Kota Surakarta periode 1999-2004.

$\mathbf{X}$ adalah orang yang aktif di berbagai organisasi masyarakat dan kegiatan sosial. Melalui berbagai lembaga yang digelutinya tersebut, $\mathbf{X}$ mendapatkan banyak dukungan suara sehingga akhirnya terpilih menjadi anggota DPRD. Untuk menjadi anggota dewan ini, $\mathbf{X}$ sama sekali tidak mengeluarkan uang. Masyarakat sekitarnya mengetahui reputasinya selama ini sebagai orang yang baik dan amanah. Dia menantu seorang tokoh agama yang cukup dikenal di kota ini. Menurut banyak rekannya, $\mathbf{X}$ termasuk orang yang jujur dan lurus.

Saat menjalankan tugas sebagai anggota dewan, di tengah perjalanannya, sebenarnya $\mathbf{X}$ sudah ingin mundur dan digantikan oleh temannya melalui sistem pergantian antar waktu (PAW), namun temannya tidak bersedia. Ketika menjalani sidang korupsi di DPRD ini, $\mathbf{X}$ memang terlihat yang paling siap dalam menjalani pemeriksaan pengadilan dibanding terdakwa-terdakwa lainnya. Anggota dewan yang dikenal vokal ini siap menanggung risiko atas segala keputusan yang diambil bersama secara "berjamaah" oleh seluruh anggota dewan.

Kasus korupsi dana Anggaran Pendapatan dan Belanja Daerah (APBD) 2003 yang dilakukan oleh 13 anggota DPRD Kota Surakarta periode 1999-2004 ini merupakan kasus pemberantasan korupsi di lembaga legislatif yang pertama kali diangkat ke pengadilan di Indonesia. Yang menjadi fokus permasalahan dalam korupsi ini khususnya pada pos belanja lain-lain dalam APBD 2003 senilai Rp 9,8 miliar. Pos yang diyakini telah terjadi penyimpangan adalah pos dana asuransi yang masuk ke rekening pribadi setiap anggota dewan.

Menurut UU Nomor 4 Tahun 1999 dan UU Nomor 22 Tahun 1999, DPRD memang memiliki kewenangan untuk menentukan jumlah kenaikan anggaran fasilitas anggota dewan. Dengan wewenang ini, mereka menetapkan kenaikan biaya, fasilitas, maupun tunjangan untuk anggota DPRD periode 1999-2004 yang menjadikan penghasilan anggota DPRD bertambah dan terbukti untuk memperkaya diri sendiri. Mark-up anggaran terjadi hingga mencapai $100 \%$. Para terdakwa dianggap melanggar UU Nomor 20 Tahun 2001 tentang Pemberantasan Tindak Pidana Korupsi. Pasal ini berfokus pada tindakan yang merugikan keuangan negara, memperkaya diri pribadi, dan penyalahgunaan wewenang yang mengakibatkan terjadinya kerugian keuangan negara.

\section{Kasus Korupsi Sistematik oleh $\mathbf{Y}$}

Y berusia 30 tahun, pendidikan sarjana hukum, menjadi penyalur dana aspirasi dari salah satu anggota DPRD Jawa Tengah, dihukum 2 tahun subsider 4 bulan penjara. Y melakukan korupsi aliran dana aspirasi dari salah satu anggota DPRD Jawa Tengah. 
Y mengaku sebagai orang yang keras kepala, tidak mau mendengar nasihat dari orang lain dan keluarganya, serta semua urusan dia ingin kerjakan sendiri. Termasuk ketika $\mathbf{Y}$ dekat dengan $\mathbf{Z}$ (salah seorang anggota DPRD Jawa Tengah yang memiliki kewenangan untuk membagikan dana aspirasi), seluruh anggota keluarga dan istrinya telah menasihatinya agar jangan terlalu dekat dengan anggota dewan, namun $\mathbf{Y}$ tidak memedulikannya.

Y, ketua suatu perkumpulan petani buah di kabupaten $\mathrm{W}$, mengenal $\mathbf{Z}$ melalui sebuah lembaga swadaya masyarakat (LSM), di mana $\mathbf{Z}$ juga terlibat di dalamnya. $\mathbf{Y}$, yang menjadi penyalur dana tersebut, dianggap telah melakukan penyelewengan dana aspirasi senilai Rp 250 juta.

Sebenarnya, tuduhan korupsi ini terjadi karena $\mathbf{Z}$ tidak mau membuatkan kuitansi untuk pengeluaran dana itu sehingga publik menduga bahwa Y-lah yang melakukan korupsi tersebut. Selama ini, di Indonesia, hukum berjalan berdasarkan bukti, dan $\mathbf{Y}$ tidak memiliki bukti yang sah tentang penyaluran dana itu. Sementara itu, $\mathbf{Z}$ yang menjadi penggagas penyaluran dana aspirasi, justru, tidak mau bertanggung jawab atas kasus yang menimpa $\mathbf{Y}$.

Hasil penelitian ini merupakan analisis dari dua kasus korupsi (sistemik dan sistematik), yang diarahkan pada lima kajian utama, yaitu: (1) definisi korupsi; (2) motif melakukan korupsi; (3) proses terjadinya korupsi; (4) dampak melakukan korupsi; dan (5) cara mengatasi masalah (coping) akibat korupsi.

\section{Definisi korupsi}

Definisi korupsi menurut informan: (1) Korupsi merupakan penyalahgunaan jabatan untuk kepentingan sendiri; (2) Korupsi identik dengan pencurian, (3) Sesuatu yang tidak berjalan sesuai dengan aturan yang sesungguhnya; dan (4) Korupsi berarti menggunakan uang negara secara sengaja dan direncanakan untuk kepentingan pribadi maupun kelompok.

\section{Motif melakukan Korupsi}

Motif melakukan korupsi yang dilakukan oleh informan: (1) Melakukan korupsi karena faktor solidaritas; (2) Adanya sistem yang memungkinkan terjadinya korupsi (karena adanya UU Nomor 4/1999 dan Nomor UU 22/1999 yang menyatakan bahwa DPRD mempunyai kewenangan untuk mengatur anggaran sendiri serta karena informan ikut masuk menjadi panitia anggaran); (3) Mendapatkan uang; dan (4) Mendapatkan pekerjaan.

Seperti yang disampaikan oleh $\mathbf{X}$, bahwa:

"Saya melakukan ini karena faktor solidaritas saja, saya enggak enak sama teman-teman yang sudah menyetujui anggaran ini. Sehingga, untuk kasus saya secara pribadi, saya tidak tahu di mana korupsinya, karena DPRD memang diberi wewenang untuk mengatur sendiri anggarannya. Jadi, aturan mana yang kita langgar? Semua aturan itu kan dari pusat. Saya terjebak dalam sistem. Tapi karena saya masuk sebagai panitia anggaran, maka jelas saya bisa dihukum. Dan ini tidak adil menurut saya. Jadi, kalau memang saya terbukti, saya rela dihukum seberat-beratnya, saya rela dipotong tangan. Andaikan hasil rapat itu dianggap sebagai konspirasi dalam pengambilan kebijakan, toh, saya juga tidak ada di situ.Tapi kalau untuk teman-teman yang lain, motifnya jelas, uang itu menjadi faktor utama, untuk memperkaya diri sendiri."(Wawancara dengan $\mathbf{X}$, pada 3/5/2010). 
Proses Terjadinya Korupsi

Proses terjadinya korupsi menurut informan disebabkan: (1) Proses pembuatan anggaran dilakukan oleh lembaga legislatif bersama dengan lembaga eksekutif; (2) Dengan cara memperbesar anggaran, fasilitas maupun tunjangan untuk anggota dewan melalui celah-celah hukum yang ada; (3) Semua laporan administratif dimanipulasi, dijadikan sedemikian rupa, dan dibuat 'terlihat' rapi serta seakan-akan sesuai prosedur; (4) Terjadi mata rantai korupsi yang saling berkaitan, baik pada tingkat eksekutif, legislatif, yudikatif, kepolisian, bahkan pada LSM yang tadinya bermaksud untuk membongkar kasus korupsi (terjadi tindak korupsi yang diikuti dengan tindak korupsi yang lain); dan (5) Penyaluran dana aspirasi tanpa memakai bukti kuitansi.

"Saya melihat kasus korupsi diwarnai dengan kasus-kasus korupsi yang lain. Saya mohon maaf, berkata apa adanya, tapi ini mungkin bisa terjadi juga kepada orang yang tersandung masalah ini, yakni kemudian munculnya korupsi di kejaksaan, di pengadilan, dan lain sebagainya. Ada bergaining-bergaining yang harus kita tempuh, dan itu ditawarkan secara terang-terangan." (Wawancara dengan X, pada 3/5/2010).

"Dia memberikan bantuan ke teman-teman saya, melalui saya. Saya diminta jadi perantaranya. Tapi waktu saya menyerahkan uang, tidak pakai kuitansi, karena memang proses penyalurannya melalui 3 cara, yaitu lewat rekening, secara langsung, dan ada yang sebagian untuk membayarkan hutangnya si Z. Nah, yang ditransfer lewat rekening itu kan tidak saya simpan (buktinya). Dan Z juga tidak mau membuatkan kuitansi untuk pengeluaran dana itu. Jadi, teman-teman mengira saya telah melakukan korupsi. Tapi, malah $\mathbf{Z}$ tidak dijadikan saksi apalagi tersangka. Saya tidak tahu, apa ada permainan di balik itu semua." (Wawancara dengan $Y$, pada 15/5/2010).

\section{Dampak terhadap Pelaku Korupsi}

Dampak terhadap pelaku korupsi: (1) Mendapatkan hikmah berharga karena masuk penjara yang merupakan "suatu lembaga pendidikan" yang tidak ternilai harganya serta bisa belajar banyak hal tentang kehidupan dan perilaku manusia di dalamnya, sehingga membuatnya jadi lebih bijak dalam menjalani kehidupan di masa mendatang; (2) Masuk penjara (dengan masuk ke penjara, secara otomatis, memang telah menyengsarakannya, studi pascasarjana di suatu perguruan tinggi yang sedang dijalani mengalami ketertundaan, kebebasan sebagai manusia normal menjadi jadi terbatas, serta nama dan harga diri jadi buruk, selain itu, ijazah sarjana yang sudah dimiliki juga tidak bisa dipakai untuk mendapatkan pekerjaan di sektor formal); (3) Dampak terhadap keluarga (keluarga besar harus menanggung malu akibat adanya keluarga yang masuk penjara akibat didakwa melakukan korupsi, istri harus mencari nafkah sendiri karena suami sebagai kepala keluarga sudah tidak bisa diandalkan untuk menjadi sumber pencari nafkah bagi keluarga, namun di sisi lain, istri tidak bisa mendapatkan kredit/hutang ke bank, karena suaminya ditahan sehingga dia masuk dalam kelompok daftar hitam (black list), selain itu juga, timbul kekhawatiran akan munculnya efek psikologis yang kurang baik pada keluarga nantinya, khususnya pada anaknya); dan (4) Memiliki hutang baru yang lebih besar, untuk menutup hutang lama yang sebelumnya dimiliki.

"Saya berterima kasih karena dimasukkan ke sebuah institusi pendidikan yang mahal harganya karena itu merupakan pembelajaran dan hikmah terbesar dalam 
hidup saya. Saya justru pernah mendapat penghargaan dari LP tingkat Kanwil karena menggiatkan aktivitas keagamaan di sana, sampai sekarang hampir setiap hari selalu ada pengajian." (Wawancara dengan $\mathbf{X}$, pada 3/5/2010).

"Dampaknya banyak yang negatif, walaupun saya yang nanggung tapi nama keluarga besar saya juga jadi ikut jatuh di masyarakat. Saya juga khawatir nanti anak saya kalau dibilang: "Oh, itu bapaknya kan mantan tahanan"." (Wawancara dengan $\mathbf{Y}$, pada $15 / 5 / 2010$ ).

Cara Mengatasi Masalah (Coping) Akibat Korupsi

Informan cenderung menggunakan emotion focused coping dibandingkan dengan problem focused coping dalam menghadapi masalahnya. Informan cenderung untuk melakukan, seperti: (1) Self-control; berusaha untuk mengatur perasaannya, tidak terlalu memedulikan masalahnya agar tidak semakin tertekan; (2) Positive reappraisal; dengan melakukan spiritual coping, seperti berserah diri pada Tuhan, ikhlas dan pasrah, banyak ber-istighfar, serta beribadah shalat malam; dan (3) Accepting responsibility (mencoba "menerimanya" untuk membuat semuanya menjadi lebih baik); seperti memasrahkan diri agar hati dan pikiran menjadi lebih tenang.

\section{Diskusi}

Secara umum, dari kasus korupsi sistemik maupun sistematik yang terjadi di atas, selalu saja masyarakat belum merasakan reformasi hukum. Masih banyak kasus yang tidak diproses dengan sebenarnya dan seadil-adilnya. Banyak faktor yang melingkupi di dalamnya, antara lain melibatkan unsur kepolisian, kejaksaan, dan pengadilan, yang ujung-ujungnya ditentukan oleh uang.

Hal yang akan ditarik dari fenomena ini bukanlah untuk menjawab apakah korupsi semakin tinggi atau semakin rendah, siapa pelakunya, seberapa sering, atau dimana letak korupsinya, namun penelitian ini lebih memfokuskan pada motif, proses, dan dampak korupsi bagi pelaku korupsi.

Berdasarkan kasus yang terjadi pada X, sebagai pelaku korupsi sistemik, bisa dilihat bahwa kendati orang Indonesia tidak setuju dengan korupsi dan merasakannya sebagai hal yang merugikan masyarakat, namun ketika mereka berada dalam suatu sistem, mereka justru terlibat di dalamnya, tidak mampu untuk menolak, muncul perasaan tidak berdaya untuk "berbeda" dari kelompoknya, serta kurangnya "bantuan" dari luar untuk menolak korupsi. Ketidakberdayaan untuk, akhirnya, meniru lingkungan inilah yang kemudian menyebabkan timbulnya korupsi di masyarakat. Alasan $\mathbf{X}$ melakukan solidaritas terhadap teman-teman kerjanya di DPRD lebih dikedepankan daripada memikirkan kepentingan masyarakat luas. Memang, dalam kultur Indonesia, struktur sosial organisasi, kepemimpinan, normanorma budaya dan sistem insentif memainkan peran penting (Darley, Messick, \& Tyler, 2001). Demikian pula dengan budaya kebersamaan atau budaya kolektif. Budaya kolektif lebih diutamakan dan lebih diterima agar seseorang tidak dicap sebagai orang yang individualis, meski kadang kolektivisme ini juga dilakukan dalam hal-hal yang tidak baik serta bertentangan dengan norma hukum dan agama. Fenomena ini mendukung banyaknya penelitian yang telah dilakukan sebelumnya bahwa individu-individu dalam budaya kolektivis bisa lebih korup 
dibandingkan dengan budaya individualis (Rethi, 2012).

Meski demikian, menurut $\mathbf{X}$ bahwa yang paling bertanggung jawab terhadap kasus ini, sebenarnya, bukanlah dirinya sendiri atau pun anggota dewan yang lain, namun penanggung jawab utama adalah pemerintah pusat, karena pemerintah telah mendesain sebuah sistem kebijakan (dalam hal ini adalah PP 110/2000) yang memberikan kebebasan pada anggota dewan untuk menentukan jenis-jenis pendapatan yang dapat diterima oleh mereka dengan besar tunjangan/pendapatan dan biaya kegiatan yang sudah ditetapkan, namun sebenarnya PP 110/2000 ini bertentangan dengan UU 4/1999 dan UU 22/1999 yang menyatakan bahwa DPRD memiki kewenangan untuk mengatur anggarannya sendiri. Meski demikian, pada pelaksanaannya, wewenang untuk mengatur anggaran DPRD ini terkesan "jor-joran" dari segi besaran anggarannya di banyak daerah. Hal ini yang kemudian menjadi sorotan publik. Jadi, dari kasus ini bisa dilihat, jika persepsi masyarakat tentang korupsi saja belum sama, sehingga korupsi menjadi sulit untuk diberantas.

Sementara itu, selama ini, pejabat (baik eksekutif maupun legislatif) umumnya akan mencampuradukkan antara peran publik mereka dengan kepentingan (baca: keinginan) pribadi. Sumber penghasilan mereka tidak diatur secara jelas dan sering ditentukan secara sewenangwenang melalui sistem perlindungan yang terkait dengan budaya diam, sehingga mendukung adanya perlindungan tersebut. Situasi ini mendorong dan mendukung terjadinya praktik korupsi. Korupsi itu sudah mendarah daging sehingga perlu dibuat terminologi dan undangundang hukum baru tentang korupsi karena orang sudah tidak malu lagi untuk melakukan korupsi. Mereka takut dengan hukuman penjara jika ketahuan. Kalau tidak ketahuan, maka tidak apa-apa melakukan korupsi. Sehingga perlu dibuat terapi kejut (shock therapy) agar pelaku korupsi tidak mengulanginya lagi.

Fenomena seperti inilah yang dikatakan oleh Muhammad Hatta -Wakil Presiden pertama Republik Indonesia- bahwa "korupsi yang terjadi di Indonesia sudah menjadi bagian dari kebudayaan...." (Tempo, 2001). Sehingga, ketika diketahui bahwa sistem pemberlakuan hukum di Indonesia sudah sangat rusak maka masyarakat luas akan pesimis dan merasa tidak perlu lagi terus berharap agar sistem ini bisa berfungsi dengan baik.

Perasaan pesimis masyarakat terhadap penyelesaian korupsi mungkin akan lebih bertambah lagi ketika mengetahui bahwa dari ke-13 terdakwa korupsi APBD ini, pada kasus korupsi yang terjadi pada $\mathbf{X}$, ada empat orang yang berasal dari fraksi TNI (ketika itu, fraksi TNI belum dihapus), yang akhirnya diputus bebas oleh pengadilan militer.

Para aktivis antikorupsi (termasuk MAKI) mungkin akan merasa puas ketika tahu laporannya ditindaklajuti oleh pengadilan dan kemudian para pelaku korupsi mendapatkan hukuman yang setimpal, namun ketika sistem hukum justru membebaskan sebagian dari mereka, maka aktivis antikorupsi dan masyarakat luas akan menjadi putus asa, dan akhirnya menjadi apatis terhadap keseluruhan isu tentang korupsi. Proses hukum di Indonesia terasa mahal, membutuhkan waktu yang lama, dan penuh dengan ketidakpastian. Padahal, masyarakat luas hendaknya mau turut serta memerangi korupsi agar terwujudnya masyarakat yang sejahtera, makmur, dan beradab akan bisa tercapai.

Berdasarkan data yang diperoleh, tampak bahwa korupsi yang terjadi secara 
sistemik mempunyai beberapa ciri, yaitu: (1) inklusif dengan lingkungan psikologis, sosial, dan budaya; (2) cenderung menjadi monopolistik; dan (3) terorganisir dan sulit untuk dihindari karena sudah menjadi proses yang rutin dan terbiasa dalam berbagai segi kehidupan sehari-hari, baik disadari maupun tidak disadari. Korupsi sistemik ini tumbuh subur pada sistem kemasyarakatan yang memiliki kompetisi politik yang rendah, pertumbuhan ekonomi yang tidak merata, civil society yang lemah, dan tidak adanya mekanisme kelembagaan yang kuat dalam menangani masalah korupsi.

Terminologi "sistem" ini bermakna komprehensif, bahkan dapat dikatakan sebagai proses signifikan. "Korupsi sudah menjadi bagian dari sistem" yang ada, sehingga cukup sulit untuk menentukan awal dimulainya antisipasi pemberantasan tindak pidana korupsi, jika dilakukan dengan pendekatan psikologis.

Berdasarkan pada kasus $\mathbf{X}$, tampak bahwa teori belajar sosial (social learning) berlaku dalam hal ini. $\mathbf{X}$ melakukannya karena lingkungan sekitarnya juga berbuat hal yang sama, demikian pula, yang dilakukan oleh kejaksaan, pengadilan, kepolisian, dan lembaga swadaya masyarakat. Korupsi sudah menjadi mata rantai yang saling berkaitan. Korupsi di Indonesia sudah sangat terstruktur dan masif, yang terjadi dari tingkat hulu sampai hilir, dari pejabat di pusat hingga ke pelosok desa. Baik bentuk korupsi sistematik maupun sistemik dapat diminimalkan jika terdapat kemauan politik dari para elit politik, sebuah resolusi yang ditunjukkan secara meyakinkan, untuk menghilangkan sebab dan akibat korupsi pada tingkatan sistemik.

$\mathbf{X}$, meskipun bukan merupakan pribadi yang tamak dan haus akan harta namun ketika dia ikut terlibat dalam sistem atau lembaga yang tidak tertata dengan baik, maka dia juga akan mengikuti jejak langkah "teman-teman dan para pendahulunya". Tanpa menjadi seorang pribadi yang rakus pun, ketika seseorang sudah masuk ke dalam sistem, maka akan sulit untuk keluar dari mental dan budaya korupsi yang sudah lama mengakar tersebut. Ditambah pula, jika ada beberapa faktor yang tergabung, yaitu memiliki mental yang serakah, sistem yang buruk, serta pelaku penegak hukum yang lemah, maka sempurnalah sudah koalisi praktik korupsi di negara Indonesia ini.

Sementara itu, berkaca pada kasus $\mathbf{Y}$, tampak bahwa dia kurang kuat dalam melakukan penolakan untuk tidak bekerja sama dengan Z. Padahal, untuk tidak pernah melakukan korupsi dibutuhkan komitmen, semangat, konsistensi dan pendirian yang teguh. Meskipun $\mathbf{Y}$ tahu bahwa yang paling dipersalahkan dalam kasusnya adalah si penggagas penyaluran dana aspirasi itu, yaitu $\mathbf{Z}$.

Masih banyak muncul anggapan dari masyarakat arus bawah bahwa jika ada pejabat yang melakukan korupsi itu sudah wajar karena memang sedang memiliki kewenangan untuk mengatur masalah itu. Yang penting, hasil dari korupsi itu harus dibagi-bagi, tidak untuk diri sendiri. Rakyat (konstituen) perlu didatangi, diberi oleh-oleh, dan diberi sedikit proyek. Maka mereka akan senang sekali. Hal inilah yang terjadi pada kasus $\mathbf{Y}$.

Tampaknya, pemerintah perlu memikirkan lebih lanjut tentang fenomena dana aspirasi ini, dengan meminta pendapat dari pakar hukum atau pakar keuangan, tentang bagaimana sebenarnya status dan legalitas dana aspirasi ini? Apakah benar seorang anggota dewan bisa memiliki wewenang untuk memberikan dana kepada rakyat? Bukankah anggota dewan memiliki fungsi sebagai legislatif, mem- 
buat anggaran, serta mengawasi kerja eksekutif? Bolehkah lembaga legislatif berperan ganda sekaligus, di luar wewenang kerjanya, dengan menjadi eksekutif?

Ketika seorang anggota DPRD memperjuangkan daerah pemilihannya (dapil), sebenarnya, adalah hal yang biasa bahkan malah wajib, sebab mereka (rakyat) pula yang telah menghantarkan beliau sehingga akhirnya bisa duduk di jajaran anggota dewan yang terhormat. Meski, hal yang dipersoalkan kemudian adalah anggota DPRD tersebut memiliki motif untuk mencari kepopuleran dan keuntungan pribadi, baik yang berupa uang, dukungan suara untuk periode Pemilihan Umum (Pemilu) yang akan datang, atau agar partainya dianggap bersungguh-sungguh berjuang untuk rakyat. Padahal dana aspirasi itu sebenarnya berasal dari rakyat juga yang diwujudkan dalam bentuk APBN/APBD.

Selama ini, masih banyak masyarakat yang berperilaku meniru tindakan/model dari orang lain (yang mungkin dianggap lebih senior, lebih kaya, pintar, mapan, dan sebagainya). Tanpa melihat bagaimana sebenarnya hakikat perilaku tersebut, terpuji ataukah tercela. Perilaku ini bisa terjadi tanpa disadari oleh masyarakat. Seseorang perlu diingatkan terus akan bahaya dari korupsi ini karena dalam kehidupan sehari-hari mereka melihat, mengalami, dan terbiasa dengan sistem dan budaya korupsi yang sudah mapan berakar dan, bahkan, menghunjam jauh ke bumi. Oleh karena itu, seperti yang disarankan oleh Maurice Punch (2000) dalam penelitiannya, bahwa: (1) korupsi tidak bisa dihilangkan secara temporer, tapi perlu dibasmi secara terus-menerus, konstan, dan represif, serta (2) perlu tindakan efektif untuk menghilangkan korupsi, antara lain, memiliki kepemimpinan yang kuat, memiliki strategi organisasi yang multifaceted (melihat dari berbagai segi), sumber daya manusia (SDM) internal yang mumpuni, adanya teknik yang proaktif dalam melakukan investigasi, dan upaya yang gigih untuk meningkatkan standar profesi kerja. Dengan kata lain, fokus pada pengejaran terhadap para pelaku korupsi tetapi mengabaikan pencarian terhadap akar penyebab bisa memberikan hasil yang negatif dalam menurunkan angka korupsi.

\section{Kesimpulan}

Hasil penelitian ini merupakan analisis dari dua kasus pengalaman informan dalam melakukan korupsi (sistemik dan sistematik). Makna pengalaman informan ini dikelompokkan menjadi lima kajian utama, yaitu: (1) Definisi korupsi, yaitu penyalahgunaan jabatan, identik dengan pencurian, tidak berjalan sesuai dengan aturan yang sesungguhnya, dan penggunakan uang negara secara sengaja untuk kepentingan pribadi maupun kelompok; (2) Motif melakukan korupsi, yaitu karena faktor solidaritas dengan teman-temannya, adanya sistem yang memungkinkan terjadinya korupsi, untuk mendapatkan uang dan pekerjaan; (3) Proses terjadinya korupsi, yaitu pembuatan anggaran yang dilakukan oleh lembaga legislatif bersama dengan lembaga eksekutif, memperbesar anggaran, fasilitas maupun tunjangan untuk kepentingan mereka, laporan administratif dimanipulasi, mata rantai korupsi yang saling berkaitan, dan penyaluran dana aspirasi tanpa memakai bukti kuitansi; (4) Dampak terhadap pelaku korupsi, yaitu mendapatkan hikmah hidup yang berharga; masuk penjara; berdampak pada keluarga dan memiliki hutang baru yang lebih besar; serta (5) Cara mengatasi masalah (coping) akibat korupsi, yaitu menggunakan emotion focused coping. 
Melihat fenomena korupsi di atas, maka penulis memberikan saran kepada: (1) Negara/pemerintah; untuk melakukan reformasi hukum yang menitikberatkan pada rasa keadilan, keamanan dan kenyamanan rakyat, serta memperkuat institusi dan substansi hukum yang terkait dengan masalah korupsi dan memberikan sanksi yang tegas kepada mereka yang terlibat dalam tindak korupsi, (2) Lembaga legislatif; untuk menjadikan posisi anggota dewan sebagai sarana pengabdian kepada rakyat, serta turut serta menjalankan reformasi di dalam lembaga legislatif sendiri dan memperkuat strategi pemberantasan korupsi, (3) Media massa dan masyarakat; perlu menyebarkan informasi tentang perlunya melawan korupsi dan berani menyuarakan rasa keadilan, dan (4) Tokoh agama, untuk lebih sensitif terhadap kasus korupsi.

Sementara, bagi para peminat penelitian kualitatif, khususnya yang menggunakan pendekatan fenomenologi, penulis perlu menggarisbawahi bahwa sebagai penelitian yang bersifat investigative reporting, penelitian ini memerlukan waktu pelaksanaan penelitian yang lebih lama, sehingga memerlukan keuletan serta kesabaran dalam melakukan analisis.

Hasil penelitian ini diharapkan dapat menambah referensi dan mendorong penelitian tentang korupsi di masa mendatang. Kajian ini perlu diperdalam dengan menambah jumlah responden dan memperluas daerah yang diteliti agar memberikan informasi yang lebih komprehensif, objektif dan berimbang.

\section{Kepustakaan}

Acham, K. (1981). 'Formen und Folgen der Korruption', in C. Brünner (ed.) Korruption und Kontrolle, Wien.
Alatas, S. H. (1975). Sosiologi Korupsi. Jakarta: LP3ES

Alatas, S. H. 1987. Korupsi: Sifat, Sebab, dan Fungsi. Jakarta: LP3ES.

Alesina, A., \& Angeletos, G. M. (2005). Corruption, Inequelity, and Fairness. Journal of Monetary Economics, 52(7), 1227-1244.

Bauhr, M., Nasiritousi, N., Oscarsson, H., \& Persson, A. (2010). Perceptions of Corruption in Sweden. QoG Working Paper Series, 8, 1-17.

Baswir, R. (1993). Ekonomika, Manusia, dan Etika, Kumpulan Esai-Esai Terpilih. Yogyakarta: BPFE.

Burhan, A. S., Waidl, A., \& Ismail, B. (2004). Korupsi di Negeri Kaum Beragama - Ikhtiyar Membangun Fiqh Anti Korupsi. Jakarta: P3M dan Kemitraan.

Carver, C., Scheier, M., \& Weintraub, J. (1989). Assessing Coping Strategies: A Theoretically Based Approach, Journal of Personality and Social Psychology, 56, 267-283.

Creswell, J. W. (1998). Qualitative Inquiry and Research Design: Choosing Among Five Traditions. Thousand Oaks, California: Sage Publications.

Darley, J. M., Messick, D. M. \& Tyler, T. R. (Eds.) (2001). Social Influences on Ethical Behavior in Organizations. Mahwah, NJ: Lawrence Erlbaum Associates.

Darsono. (2001). Korupsi sebagai Kompensasi Underpayment: Suatu Tinjauan Teori Equity. Jurnal Bisnis dan Akuntansi, 3(2), 477-487.

Drew, N. (1989). The Interviewer's Experience As Data in Phenomenological Research. Western Journal of Nursing Research, 11, 431-439.

Fleming, J. E. (2004). The Need for Ethics in Business. The Academy of Management News, 35(2), 5. 
Folkman, S. (1984). Personal Control and Stress and Coping Processes: A Theoritical Analysis. Journal of Personality and Social Psychology, 46, 839-852.

Graaf, G. D., \& Huberts, L. W. J. C. (2008). Portraying the Nature of Corruption Using an Explorative - Case Study Design. Jurnal Public Administration Review, July-August, 640-653.

Graeff, P. (2005). Why Should One Trust in Corruption? The Linkage between Corruption, Norms, and Social Capital, dalam The New Institutional Economics of Corruption. J.G. Lambsdorff, M. Taube, \& M. Schramm (ed.), Routledge: Abingdon, Oxon RN.

Holmberg, S. (2009) Perceptions of Corruption in Mass Publics, QoG Working Paper Series, 24, The Quality of Government Institute, Gothenburg.

Huntington S. P. (1968). Political Order in Changing Societies. New Haven: Yale University Press

Irwan, A. (2003). Jurnal Wacana: Pemberantasan Korupsi sebagai Gerakan Budaya. Yogyakarta: Insist Press.

Jarvis, M. (2000). Theoretical Approaches in Psychology (terj.), London: Routledge.

Jones, P. C., \& Bates, J. G. (1990). Public Sector Auditing: Practical Techniques for an Integrated Approach. First Ed. London: Chapman and Hall.

Jurnal Aksara, Tempo, 19/2/2001.

Lambsdorff, J. G. (1999). Corruption in Empirical Research - A Review, Transparency International Working Paper.

Lazarus, R. S., \& Folkman, S. (1984). Stress, Appraisal and Coping. New York: Springer Publishing Company

Lazarus, R. S., \& Folkman, S. (1988). Ways of Coping Questionnaire. Permission set, manual, test booklet and scoring key. Palo
Alto, CA: Consulting Psychologists Press.

Lianawati, E. (2009). Konflik Dalam Rumah Tangga - Keadilan Tanpa Kepedulian Proses Hukum KDRT - Perspektif Psikologi Feminis. Yogyakarta: Paradigma Indonesia.

Lincoln, Y. S., \& Guba, E. G. (1985). Naturalistic Inquiry. Beverly Hills, CA: Sage.

Masduki, T. Sengsarakan Koruptor. Kompas, 24/8/2010.

Moustakas, C. (1994). Phenomenological Research Methods. Thousand Oaks, CA: Sage.

Morgan, A. L. (1998). Corruption: Causes, Consequences, and Policy Implications. San Fransisco: Asia Foundation working paper series, 9.

Muluk, H. (2008). Psikologi Korupsi. Seputar Indonesia, 2/5/2008.

Na'im, M. M., Rofi'ah, N., \& Rahmat, I. (2006). NU Melawan Korupsi: Kajian Tafsir dan Figh. Jakarta: Tim Kerja Gerakan Nasional Pemberantasan Korupsi PBNU.

Nye, C. J. (1967). Corruption and Political Development: A Cost-benefit Analysis. American Political Science Review, 61(2), 417-427.

Oiler, C. (1982). The Phenomenological Approach in Nursing Research. Nursing Research, 31, 178-181.

Paldam, M. (2001). Corruption and Religion - Adding to the Economic Model. KYKLOS, 54, Fasc. 2/3, 384-414.

Patton, M. Q. (1990). Qualitative Evaluation and Research Methods. 2nd Edition. London: Sage.

Pope, J. (1999). Elements of a Successful Anticorruption Strategy dalam Rick Stapenhurst, Sahr John Kpundeh, 
Curbing Corruption: Toward A Model For Building National Integrity, Washington DC: The World Bank

Pei, M. (1999). Apakah Cina akan Menjadi Indonesia yang Lain? Washington: Foreign Policy.

Punch, M. (2004). Police Corruption and Prevention. European Journal on Criminal Policy and Research, 8(3), 301-324.

Purwantari, B. I. Mempertanyakan Banalitas Korupsi. Kompas, 30/8/2010.

Regar, M, H. (1998). Peranan Forensic Accountant Menemukan Tindak Korupsi. Makalah, disajikan dalam seminar yang dilaksanakan oleh Fakultas Ekonomi Universitas Riau, Pekanbaru, 4-5 Desember.

Rethi, G. (2012). Cultural Perspectives of Corrupt Behaviour - Application of Trompenaars Model for Corruption. Club of Economics in Miskol' TMP Vol. $8,1,76-82$.

Roldan, A. (1989). A Brief Psychology of Corruption. A Journal of Human Behavior, 26(4), 53-55.

Rudel, T. K., \& Xin, X. (2004). The Context for Political Corruption: A CrossNational Analysis. Social Science Quarterly, 85(2), 294-309.

Schacter, M., \& Shah, A. (2000). Anticorruption Programs: Look Before You
Leap. Kertas kerja yang dipresentasikan untuk Konferensi Internasional tentang Korupsi yang diadakan di Seoul, Korea Selatan.

Schweitzer, H. (2005). Corruption - Its Spread and Decline, dalam J.G. Lambsdorff, M. Taube, \& M. Schramm (ed.), The New Institutional Economics of Corruption, Routledge: Abingdon, Oxon RN.

Sulistiyowati, F. (2007). Pengaruh Kepuasan Gaji dan Kultur Organisasi terhadap Persepsi Aparatur Pemerintah Daerah tentang Tindak Korupsi, JAAI, 11(1), 47-66

Sweitzer, M., \& Bicchieri, C. (2006). Diunduh dari: www.csis.org/files/ media/csis/pubs/060303_ whartonwork-shop.pdf tanggal 21/7/ 2010.

Taylor, B. (1993). Phenomenology: One Way to Understand Nursing Practice. International Journal of Nursing Studies, 30, 171-179.

Tavris, C., \& Wade, C. (1997). Psychology in Perspective, New York: Addison-Wesley Longman.

Transparency International Indonesia (2010). Diunduh dari: www.ti.or.id, tanggal 20/6/2010. 